\title{
Shear Strength and Pull-Out Response of Tire Shred-Sand Mixture Reinforced with Deformed Steel Bars
}

\author{
Beenish Jehan Khan (D), ${ }^{1}$ Irshad Ahmad (D), ${ }^{2}$ Hassan Nasir, ${ }^{1}$ Abdullah Abdullah (D), \\ and Qazi Khawar Gohar $\mathbb{B D}^{2}$ \\ ${ }^{1}$ Department of Civil Engineering, CECOS University of IT and Emerging Sciences, Peshawar, Pakistan \\ ${ }^{2}$ Department of Civil Engineering, University of Engineering and Technology, Peshawar, Pakistan \\ Correspondence should be addressed to Beenish Jehan Khan; beenish@cecos.edu.pk
}

Received 9 January 2020; Revised 20 November 2020; Accepted 30 November 2020; Published 18 December 2020

Academic Editor: Zaobao Liu

Copyright (c) 2020 Beenish Jehan Khan et al. This is an open access article distributed under the Creative Commons Attribution License, which permits unrestricted use, distribution, and reproduction in any medium, provided the original work is properly cited.

\begin{abstract}
The use of scrap tires in various engineering applications has been extensively explored. The present study has the following aim: to evaluate the suitability of tire-sand mixtures as backfill material based on its shear strength. To achieve this objective, modified Proctor compaction tests were performed on tire shred-sand mixture with mixing proportions by weight of tire shreds and sand $(0 / 100,20 / 80,30 / 70$, and 40/60) using different sizes of tire shreds $(50 \mathrm{~mm}, 75 \mathrm{~mm}$, and $100 \mathrm{~mm}$ ). Based on the results of the modified Proctor compaction test, the two mixing proportions, i.e., tire shred/sand, 20/80 and 30/70, respectively, were selected. Large-scale direct shear test indicated higher internal friction angle and cohesion values for tire shred-sand mixtures (30/70) with $100 \mathrm{~mm}$ tire size $\left(38.5^{\circ}\right.$ and $\left.19 \mathrm{kPa}\right)$ as compared with sand-only backfill material $\left(30.9^{\circ}\right.$ and $\left.0 \mathrm{kPa}\right)$. Based on stress-strain behavior plots, it was indicated that the inclusion of tire shreds imparts ductility to backfill mixtures. To achieve the second objective, the pull-out tests were performed with deformed steel bars of two different diameters $(12.7 \mathrm{~mm}$ and $15.8 \mathrm{~mm}$ ) embedded in various backfill mixtures prepared with tire shreds of three different sizes $(50,75$, and $100 \mathrm{~mm})$. The pull-out test result indicated that the deformed steel bars exhibit higher pull-out resistance in tire shred-sand mixtures $(9.9 \mathrm{kN} / \mathrm{m})$ compared with sand-only backfill material $(4.1 \mathrm{kN} / \mathrm{m})$.
\end{abstract}

\section{Introduction}

For the past many decades, scrap tires are produced in huge quantities worldwide. The nonbiodegradable nature of vulcanized rubber in tires has a serious environmental impact. According to the rubber manufacturing association (RMA), around the world, an estimated 1 billion metric tons of scrap tires are produced annually, and this amount is increasing day by day [1]. Unrecycled waste tires are a global concern due to their chemical composition, flammability, and nonbiodegradability [2]. Waste tire production has become alarming worldwide, causing the environmental and economic problems [3]. To avoid growing stockpiles, it is essential to reuse waste tires [4]. This stockpiling of scrap tires provides a suitable breeding environment for mosquitoes and other rodents. Moreover, the uncontrolled burning of tires emits heavy dark smoke, consisting of toxic compounds such as cyanide hydrogen chloride, nitrogen oxides, and gasses. The emissions present significant risks to human health and safety [5-7], according to the Maine Joint Standing Committee on Natural Resources [8]. The burning of tires releases highly toxic compounds such as dioxins and furans. These pollutants disperse in air and travel a long distance and can remain for a very long time without decomposing [9-11]. Many countries prohibit the stockpiling of scrap tires and encourage their reuse and recycling [12]. The solution to this issue is the process of recycling these huge amounts of scrap tires which are toxic waste. For the past many decades, shredded tires have been used in several civil engineering infrastructures such as pavements, retaining walls, and dams [13-15]. 
In various civil engineering applications, tires can be used as an entire tire or shreds. Compared with the entire tire, the compressibility and ease of handling of shredded tires provide more benefits. High thermal conductivity, low density, and high shear strengths at large strains make waste tires an ideal material for geotechnical applications. Tire shreds are elastic and lightweight. These unique characteristics and critical design parameters distinguish them from the soil, sand, and gravels. Tire shreds are effectively utilized in road embankments as thermal insulation layers or as backfill materials for wall retention $[16,17]$. The use of waste tires could give several advantages in the California Bearing Ratio (CBR) value of subbase material used in flexible pavement layers; the use of tire buffing and cement together is suggested both to reduce construction costs and to boost the CBR value in a flexible pavement design of a subbase material [18]. Additionally, a small amount of lime to the clay with tire buffing increases the CBR values of the specimens and thereby may cause a substantial decrease in design thickness of a highway pavement [19].

Tires are generally shredded via (a) mechanical grinding, (b) ambient scrap tire processing, (c) cryogenic crushing, (d) pyrolysis, and (e) Molectra. The mechanical grinding method is usually used as this process is cheaper than others [11]. The reduction of the tire to smaller sizes varying from $0.425 \mathrm{~mm}$ to $2 \mathrm{~mm}$ requires several cycles through the shredder, which makes the tire shreds uneconomical $[20,21]$. Hence, the use of large tire shreds would be favored from an economic perspective. American Society for Testing and Materials (ASTM) states that the size of tire shreds to be used as fragments of scrap tires should be in the range of $50-300 \mathrm{~mm}$ [12]. From an engineering perspective, tire shreds have unique properties such as improved seismic stability, high frictional resistance, availability, low cost, light weight, easy placement, exceptional rigidity, and shear strength [4, 22-27].

In the past twenty years, tire shred-sand mixture has gained wide acceptance in the construction of geotechnical projects [27]. One of the most important applications of tire shred-sand mixture is its use as backfill material in mechanically stabilized earth (MSE) walls. Tire shred-sand mixtures can be reinforced using different types of reinforcements, e.g., metal strips, metal bars, and geogrids [28, 29]. Mechanically stabilized earth (MSE) walls have several advantages over concrete retaining walls; e.g., they have a simple design, which takes less time for construction. The MSE wall is constructed with a design height of up to $\sim 19 \mathrm{~m}$, and its construction does not require especially skilled labor or heavy machinery [20, 30]. The use of the MSE wall is the economically and technically feasible solution, as it requires less site preparation compared with a traditional concrete retaining wall [31-33]. The United States (US) transportation system used MSE wall as retaining structure, bridge supports, decks departure slabs, and embankments $[34,35]$. Generally, the backfill material used in the MSE wall is clean granular cohesionless material. The sand-based backfill material can be mixed with lightweight shredded tires, sawdust, fly ash, plastic bottles, geofoam, etc. These light-weight materials help in reducing vertical stresses and lateral displacements of the retaining walls [36, 37]. The performance of the MSE wall primarily depends upon the interaction between its backfill material and components [37].

Numerous studies [5, 38-40] investigated the various fundamental parameters related to the mechanical response and the deformability of tire shred-sand mixtures. Umashankar et al. [41] evaluated the influence of tire shred size, tire shred-sand mixing ratio, and confining pressure on the interaction between the ribbed-metal strips and tire shredsand mixtures using large-scale laboratory pull-out tests. The tire shreds of sizes $9.5 \mathrm{~mm}, 50-100 \mathrm{~mm}$, and $100-200 \mathrm{~mm}$ in $0 / 100,12 / 88,25 / 75$, and $0 / 100$ (tire shred to the sand ratio by weight) backfill mixtures were used. Suksiripattanapong et al. [42] mixed well-graded gravel, well-graded sand, poorly graded sand, and crushed rock with irregular-shaped tire shreds of size in the range of $50-100 \mathrm{~mm}$. The backfill mixture consisted of different mixing ratios, and the normal pressure was applied with the help of airbags. In another study, Suksiripattanapong et al. [43] report that the frictional pull-out resistance is higher in the well-graded gravel than in the well-graded sand, poorly graded sand, and crushed stone. They observed an enhancement in pull-out friction resistance with the increase in the normal load. McCartney et al. [33] fabricated a large-scale apparatus capable of performing the direct shear test for evaluating the shear strength properties of tire-derived aggregates. The normal load was applied using dead loads and hydraulic actuators, respectively. The length, width, and height of the tire-derived aggregate sample were $3048 \mathrm{~mm}, 1220 \mathrm{~mm}$, and $1830 \mathrm{~mm}$, respectively. In the direct shear test, the apparatus permits the mobilization of peak shear strength and the values of shear stiffness and damping ratio under large strain conditions for tire-derived aggregate with large particle size. Bernal et al. [40] evaluated the interaction properties of tire shred-sand mixture with geosynthetics based on direct shear and pull-out tests. Three different sizes of flexible geogrids (with different aperture sizes) and woven geotextile embedded within two different types of fill material were used as backfill material. The backfill materials used were tire shreds and tire shred-sand mixtures. The results indicated that the backfill mixtures based on tire shreds are easy to construct, have lower lateral earth pressure, undergo limited deformation of the facing, and control the settlement.

Rahmeyer [44] confirmed the greater effectiveness of using round metal bars compared with the rectangular metallic reinforcement in MSE walls in reducing the surface contact area with soil, resulting in a lower degree of corrosion-related losses. The author asserted that the use of selecting round bars instead of steel straps as reinforcement has significant implications on the pull-out capacity of steel reinforcements in MSE walls. Corrosion may lead to decay and gradual loss of metal reinforcement, which may, in turn, lead to affecting the performance of MSE walls. Therefore, the corrosion factor should be considered when deciding on engineering designs for retaining steel-reinforced walls [45]. It was further deduced that reinforcement made with crossbars and metal round bar offers higher pull-out resistance with little to no extensibility. Pond [45] inspected 
various types of steel reinforcement and assessed their efficiencies. Based on comparative analysis between rectangular steel straps round bars in terms of corrosion resistance and pull-out strength, the author confirmed that the circular cross section holds an advantage over rectangular cross sections. The round bars are less susceptible to corrosion, which may increase the design life of the project.

Reviewing the literature, it is apparent that adequate research has been carried out to investigate the pull-out resistance of geotextile materials. However, the pull-out performance of deformed bars embedded in MSE walls has to be investigated adequately. Therefore, in this work, the effectiveness of deformed bars embedded in tire shred-sand mixtures in terms of pull-out resistance has been comprehensively investigated. To achieve this goal, two bars with diameters of $12.7 \mathrm{~mm}$ and $15.8 \mathrm{~mm}$ were used as reinforcement. Based on the results obtained, it was deduced that the pull-out resistance of deformed bars depends upon the contact area, surcharge loads, and backfill material. In addition, the shear strength parameters of tire shred-sand backfill mixtures were also evaluated using a large-scale direct shear apparatus. Therefore, the use of deformed bars as major reinforcement as well as tire shred-sand mixtures as backfill material in MSE walls proved to be an effective technique in improving their overall performance.

\section{Materials}

2.1. Sand. Locally available, poorly graded sandy soil (SP) conforming to the Unified Soil Classification System (USCS) as a primary filler was used. The particle size distribution was performed as per the standard test method for particle-size analysis of soils [46]. Figure 1(a) shows the particle-size distribution of the sand used in this study. Figure 1(b) shows the visual aspect of the sand utilized in the research. The coefficient of uniformity and coefficient of curvature were measured to be 1.75 and 1.37 , respectively. The fineness modulus for sand was measured to be 2.73 as per ASTM C33.

2.2. Tire Shreds. In this study, tire shreds with sizes of 50,75 , and $100 \mathrm{~mm}$ in were used. The $50 \mathrm{~mm}$ tire shreds were equidimensional, while the 75 and $100 \mathrm{~mm}$ tire shreds were flat and elongated. Tires were cut into the required sizes as per the ASTM D-6270 [12]. According to the geometric consideration, the length of the tire shred was measured randomly using measuring tape. The digital images of tire shreds of different sizes are shown in Figure 2.

2.3. Geometric Classification of Tire Shreds. The compaction tests performed in this study were carried out on backfill mixtures based on different sizes of tires shreds (i.e., $50 \mathrm{~mm}$, $75 \mathrm{~mm}$, and $100 \mathrm{~mm}$ ) and mixing ratios. The size of the tire shred was measured manually using a ruler. The length of the shredded piece is the greatest distance between the two furthest points. The width and depth characterize shredded pieces by giving an average dimension, which is at an angle of $90^{\circ}$ to the length of the tire shred. The tire shreds used were elongated and flat due to the fact that the length of the shred is greater as compared to its width and depth. Another representative property related to the shape of the tire shred is the aspect ratio. The aspect ratios (length/width) for $50-100 \mathrm{~mm}$ and $100-200 \mathrm{~mm}$ tire shreds were 1.6 and 2.2 , respectively [29].

2.4. Deformed Steel Bar. Round-shaped deformed steel round bars having a tensile strength of $275 \mathrm{MPa}$ were used. Figure 3 gives the visual aspect of the deformed bar used in this study. To achieve adequate contact friction, the bars having a diameter three times the diameter of average grain size $\left(D_{50}\right)$ were selected [7]. In this research, deformed bars with diameters of $12.7 \mathrm{~mm}$ (no. 4) and $15.8 \mathrm{~mm}$ (no. 5) were used. The length of the bar was kept at $214 \mathrm{~mm}$ (i.e., 0.7 times the height of the MSE wall) as specified by the Federal Highway Administration Manual (FHWA) on the MSE wall construction [47]. The pull-out capacity primarily depends on two major factors, that is, the frictional resistance between reinforcement and fill particles and the passive resistance due to the contact area and with the projections of the bar [43].

\section{Experimental Study}

3.1. Optimum Mixing Ratio of Tire Shred-Sand Mixture. A series of compaction tests were carried out to ascertain optimum mixing ratio, maximum dry density, and optimum moisture content using a modified Proctor test (ASTM 1557). To determine the appropriate mixing ratio for compacted tire shred-sand mixture, laboratory compaction tests were conducted using a compaction mould with diameter of $270 \mathrm{~mm}$. The compaction mould with larger diameter was selected to achieve adequate and homogenous mixing. The size ratio between diameter of tire shreds (50, 75 , and $100 \mathrm{~mm}$ ) and diameter of mould $(270 \mathrm{~mm})$ was in the range of 2.5-5.5.

The mass of the rammer was $9 \mathrm{~kg}$, with a drop height of $0.4 \mathrm{~m}$. The tire content in the sand was kept at $0,20,30$, and $40 \%$ (by weight) relative to sand in $0 / 100,20 / 80,30 / 70$, and $40 / 60$ tire shred-sand mixtures, respectively. The samples were prepared for different sizes of tire shred $(50 \mathrm{~mm}$, $75 \mathrm{~mm}$, and $100 \mathrm{~mm}$ ). The tire shreds and sand were airdried and compacted in five layers. Each layer was given 72 blows to achieve proper and homogenous compaction. The tire shreds and sand were compacted using the standard Proctor effort $\left(600 \mathrm{kN}-\mathrm{m} / \mathrm{m}^{3}\right)$, as described in ASTM D69800a (standard test methods for laboratory compaction characteristics of soil using standard effort) $[29,48,49]$. The procedure for specimen preparation is similar to that reported by Yoon [29].

The ratio of the mould's diameter to the tire shreds' average size with length of 100 to $200 \mathrm{~mm}$ is on the order of two and therefore size effects which will be present for this range of tire shreds. Size effects are therefore minimal for the other two tire shred sizes used in the $50 \mathrm{~mm}$ and $75 \mathrm{~mm}$ samples [50]. From the results presented in Table 1, it was observed that tire shred-sand mixture with a mixing proportion of $20 / 80$, for all the sizes of tires shreds, has the 


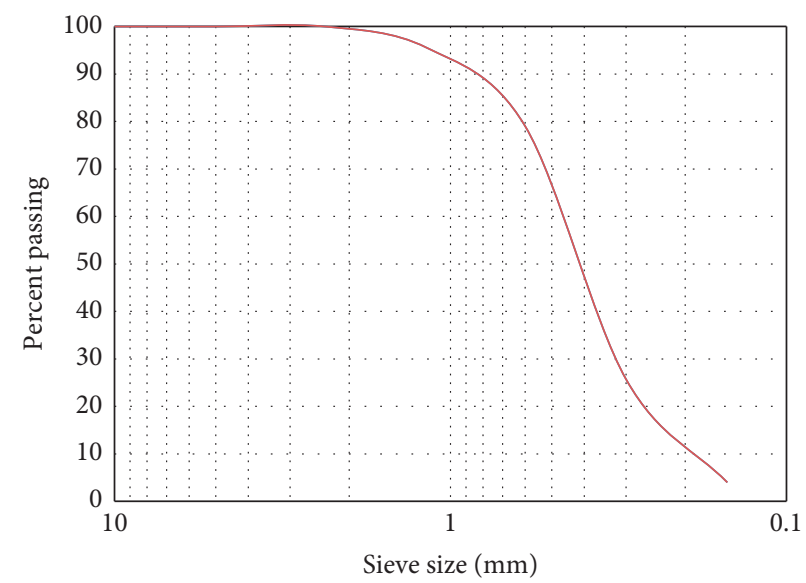

(a)

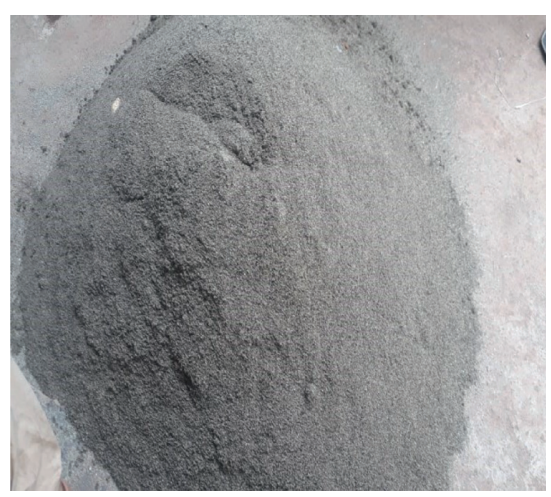

(b)

FIgure 1: (a) Particle-size distribution curve and (b) visual aspect of sand used.

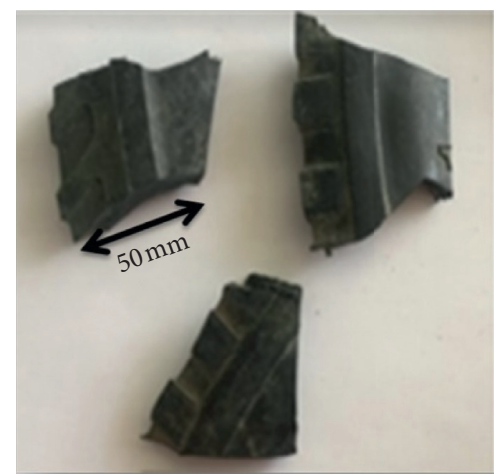

(a)

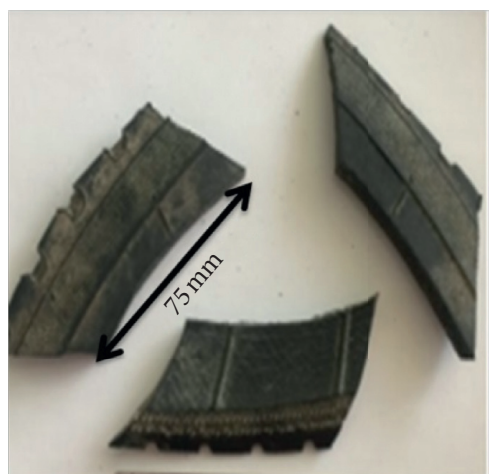

(b)

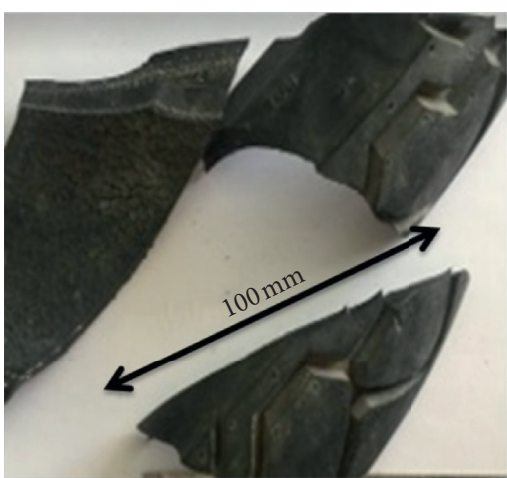

(c)

Figure 2: Visual aspect of tire shreds of different sizes (50, 75, and $100 \mathrm{~mm}$ ).

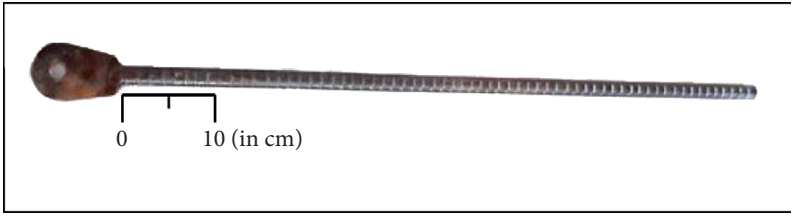

FIGURE 3: Visual aspect of deformed steel bar.

highest dry unit weight. Figure 4 represents the compaction curve for 20/80 tire shred-sand backfill mixtures with all tire shred sizes and its comparison with sand-only backfill material (0/100). As shown in Figure 4, the dry unit obtained for $0 / 100$ backfill is higher than $20 / 80$ mixtures due to the fact that the specific gravity of sand is higher than the tire shreds. Furthermore, the dry density of 20/80 backfills is observed to be a function of the size of tire shred; that is, the dry density decreases with the increase in particle size of tire shreds.

3.2. Large-Scale Direct Shear Test (LSDT) Apparatus. Figure 5 shows the large-scale direct shear test equipment as well as the pull-out test setup. The shear box was designed as per specifications given in ASTM 3080 [51]. The loading frame consisting of a rectangular steel girder frame of dimension $1.15 \times 1.46 \mathrm{~m}$ was installed on a concrete pad. The LSDT apparatus consists of upper and lower boxes having dimensions of $0.6 \mathrm{~m} \times 0.6 \mathrm{~m} \times 0.3 \mathrm{~m}$ and $0.8 \mathrm{~m} \times 0.6 \mathrm{~m} \times 0.3 \mathrm{~m}$, respectively. The upper box was fixed, while the lower one was movable. The lower box was used for both the test pull-out and the large-scale direct shear test. For normal and lateral pressures, hydraulic jacks were installed as loading devices. The vertical load was applied using a vertical jack having a capacity of $150 \mathrm{kN}$, whereas, for the application of the shearing force and pull-out force, a horizontal jack of the capacity of $100 \mathrm{kN}$ was used. Control levers were installed to control the movement of a jack at a constant rate. A $4 \mathrm{~kW}$ motor was installed for power supply to the hydraulic jack. Two load cells having the capacities of $150 \mathrm{kN}$ and $100 \mathrm{kN}$ were used to measure the normal forces and shearing forces, respectively. Two linear variable displacement transducers (LVDTs) were also installed to determine the shear and vertical displacements in the specimens. Load cells and LVDTs were attached to the data acquirement system through a data logger. 
Table 1: Modified Proctor test results.

\begin{tabular}{lccc}
\hline Shredded tires $(\mathrm{mm})$ & Proportion of mix (by weight) & $\gamma_{d}\left(\mathrm{kN} / \mathrm{m}^{3}\right)$ & OMC $(\%)$ \\
\hline Sand only & $0 / 100$ & 23.0 & 8.46 \\
\hline \multirow{3}{*}{50} & $20 / 80$ & 21.5 & 8.46 \\
& $30 / 70$ & 20.5 & 8.46 \\
\hline & $40 / 60$ & 20.0 & 8.46 \\
75 & $20 / 80$ & 19.7 & 8.46 \\
& $30 / 70$ & 19.4 & 8.46 \\
\hline & $40 / 60$ & 18.4 & 8.46 \\
\hline
\end{tabular}

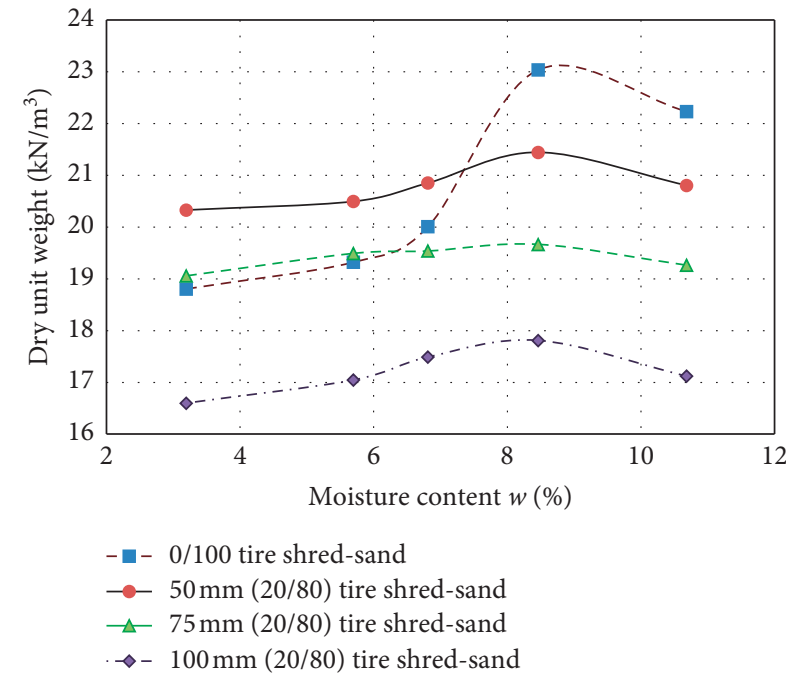

Figure 4: Results of modified Proctor test with tire shred-sand mixture with a ratio of $20 / 80$ with $50 \mathrm{~mm}, 75 \mathrm{~mm}$, and $100 \mathrm{~mm}$ tire shred size.

3.3. Data Acquisition Systems. A computer-based data acquisition setup was used for the LSDT box. The data logger was used to record the data such as shearing movement, vertical dilation, shearing force, and normal force. A personal computer, connected with a data acquisition system and Matlab software, was used to record measurements of horizontal displacement, vertical displacement, normal force, and shear strength.

3.4. Sample Preparation for LSDT. Tire shred-sand mixture was prepared using different mixing ratios. The content of tire shred in the sand was maintained at 20 and 30\% (by weight) relative to the sand and was referred to as 20/80 and $30 / 70$, respectively. Three sizes of tire shreds (50,75, and $100 \mathrm{~mm}$ ) were used. The tests were performed at three different normal stress levels $(20,30$, and $40 \mathrm{kN})$. Hand mixing of sand and tire shreds was performed in the laboratory. Afterward, the prepared mixture was shifted to the shear box and was compacted in the form of layers. The shear plane between two boxes was adjusted at the center of the compacted layers. Each layer was hand-compacted using a $5 \mathrm{~kg}$ drop-weight hammer, which consists of a steel pipe attached to a $305 \times 305 \mathrm{~mm}$ square plate $[52,53]$.
3.5. Large-Scale Pull-Out Test Setup. The pull-out test setup was fabricated, modifying the LSDT setup. The pull-out apparatus was designed according to the ASTM D6706-01 [54]. The pull-out apparatus was constructed by modifying the lower box of the large direct shear apparatus, and the protruding steel bar from a $25 \mathrm{~mm}$ circular slot on the front face of the box was connected to the load cell. The slot was sealed with a plate during the direct shear test, as shown in Figure 6(a). One end of the load cell was connected to the reinforcement through the clamp to avoid slippage of the reinforcement, while the other end was fitted to the hydraulic jack for the pull-out. The hydraulic jack was placed at the center of the slot. The normal stress was applied by vertical jack having a capacity of $100 \mathrm{kN}$ on the rigid plate placed at the top of the specimen just like in direct shear test. The displacement was measured using LVDTs attached to the front face of the pull-out box. An L-shaped sleeve was provided inside the box at the front face to transfer the pullout force beyond the rigid front face, as shown in Figure 6(b). In the absence of the sleeve, the pull-out capacity of the reinforcement could be overestimated because of the lateral pressure exerted against the walls. To reduce the frictional resistance between the walls and sample, the inner walls of the box were coated with smooth vinyl sheets. Moreover, the foam was placed at the opening to avoid the slipping of material $[23,55]$.

Pull-out resistance is the design consideration for the reinforcement embedded in backfill material. The pull-out capacity of the reinforcement is expressed as the ultimate tensile load needed to slide the reinforcement outward embedded in backfill material. According to guidelines provided by Federal Highway Administration (FHWA), the pull-out resistance per unit width of the reinforcement can be computed from the relationship given below:

$$
P_{\text {ult }}=F^{*} \alpha \sigma L_{\mathrm{e}} C,
$$

where $P_{\text {ult }}$ is ultimate pull-out capacity of the reinforcement, $\alpha$ is scale effect, and the correction factor for nonlinear stress reduction over the embedded length is taken as 1 for metallic reinforcement and 0.6 to 1 for geosynthetic reinforcement; these values are calculated from laboratory data. $\sigma$ ' is vertical normal stress at any depth between soil and reinforcement interface, $L_{\mathrm{e}}$ is adherence or embedded length in the resisting area, $C$ is effective unit parameter of the reinforcement, which is taken as 2 for the grids, strips, and sheets, and $L_{\mathrm{e}} C$ is 


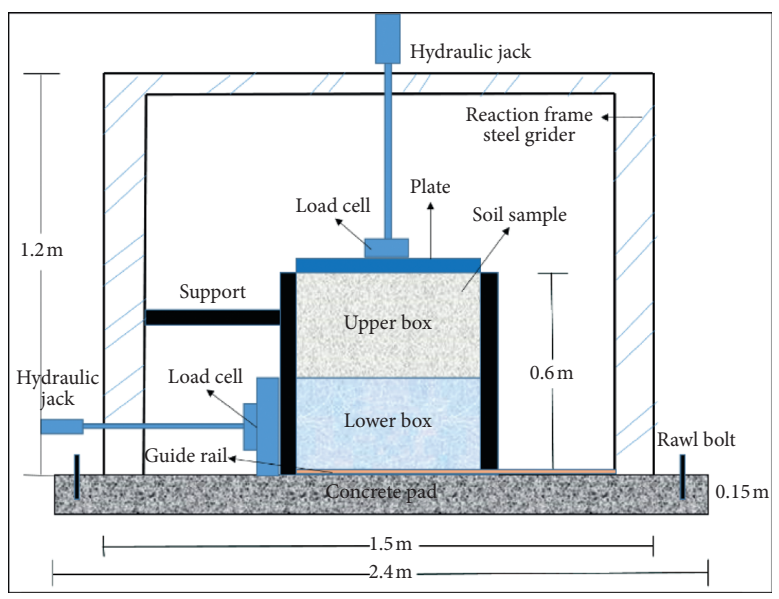

(a)

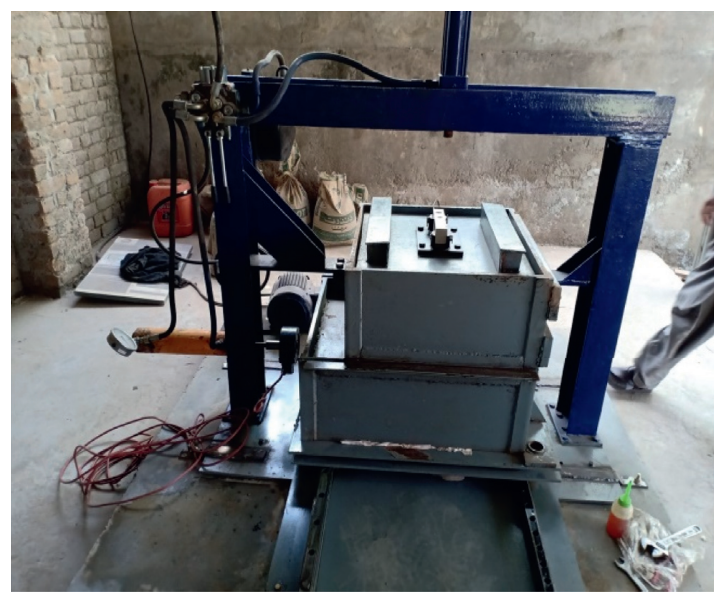

(b)

Figure 5: Schematic diagram and visual aspect of large-scale direct shear test apparatus.

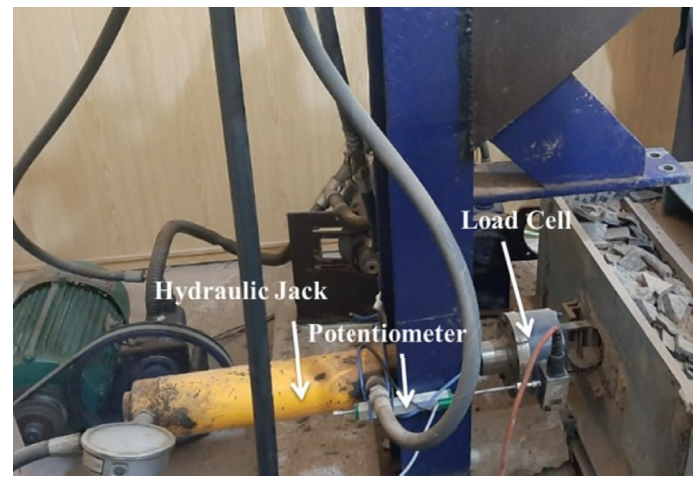

(a)

Figure 6: (a) Pull-out test setup.

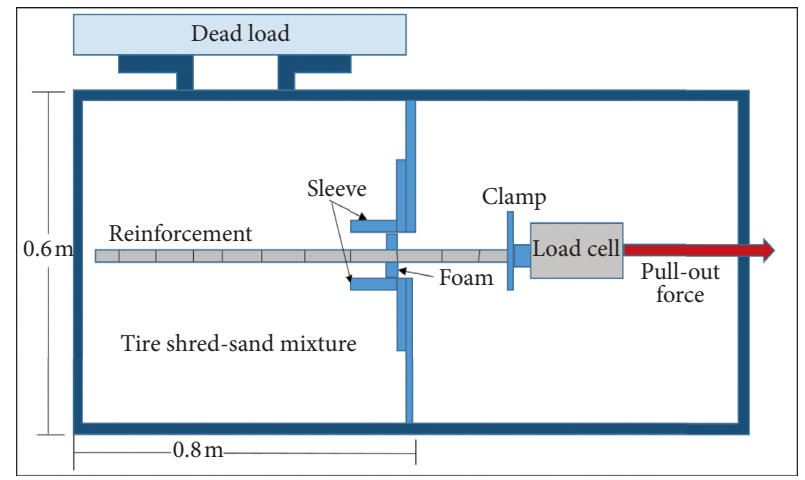

(b) total surface area per unit width of the reinforcement embedded in the resistive area behind the slip surface. $F^{*}$ is pullout resistance factor; it can be calculated from the laboratory of the field pull-out tests, or the pull-out resistance factor can be calculated from the empirical and theoretical equations formulated for interaction mechanism between soil and reinforcement. The general equation used to calculate $F^{*}$ is given below:

$$
F^{*}=\tan \rho+F q^{*} \alpha \beta,
$$

where $\tan \rho$ is the frictional resistance, $F q^{*} \alpha \beta$ is the passive resistance, $\alpha \beta$ is bearing factor for passive resistance, $\rho$ is the interaction friction angle between soil and reinforcement, and $F_{\mathrm{q}}$ is the surcharge bearing capacity factor.

3.6. Sample Preparation for Pull-Out Testing. Two diameter sizes of deformed bars $(12.7 \mathrm{~mm}$ and $15.8 \mathrm{~mm})$ were used to determine the pull-out capacity of reinforcement in tire shred-sand mixture. Forty-two tests were performed using the different combinations of deformed bars and backfill mixtures. The same mixing ratios used for LSDT, that is, $0 / 100,20 / 80$, and $30 / 70$, were used for pull-out testing. To achieve the targeted mixing ratios, the tire shreds and sand were premixed in buckets and then placed into the chamber at a very low height to reduce segregation. The sample was compacted in four equally thick layers inside the box [56]. The same hammer used for LSDT was used to compact the mixtures for pull-out testing. After compaction of the second layer, the bar was positioned in the middle of the box. The embedded length of the reinforcement was kept at $214 \mathrm{~mm}$, followed by fixing the embedded bar with the load cell to prevent slippage during testing. Subsequently, the remaining sample was compacted in the form of layers over the embedded bars. To get the representative height, the distance between the top of the sample and the top edge of the chamber is calculated at six different locations. A layer of protective sand at $3 \mathrm{~cm}$ to $4 \mathrm{~cm}$ was poured on top of the sample to level the surface. The seating lid was provided at the top of the sample to put a uniform vertical normal load by the hydraulic jack.

\section{Results and Discussion}

4.1. Large-Scale Direct Shear Test. In total, seven LSDTs were performed to estimate the shear strength of the tire shred-sand 
mixtures at different loading conditions. After the test was completed, the backfill material was removed and replaced by a newly prepared sample for further testing following the same procedure.

4.1.1. Shear Strength Parameters. Figure 7 exhibits the shear strength versus normal stress plots obtained from the largescale direct shear test (LSDT) obtained for various backfill mixtures with different tire shred particle sizes. Moreover, Table 2 collects the shear strength parameters for various backfill mixtures at a constant normal stress level of $40 \mathrm{kPa}$ obtained from Figure 7. These plots help elucidate the effect of various mixing ratios and tire shred particle sizes on the angle of friction and cohesion values. Compared with sandonly backfill mixture, the shear strength parameters (angle of friction and cohesion) are observed to increase for all tire shred-sand backfill mixtures. As is shown, an increase in percentage and size of tire shred increases the angle of internal friction and cohesion values. The largest values for the angle of friction and cohesion were obtained for 30/70 backfill mixture with $100 \mathrm{~mm}$ tires shred size, that is, $38.56^{\circ}$ and $19 \mathrm{kPa}$, respectively. The angle of internal friction increases because of the angularity of the tire shreds and their adequate interlocking with sand grains. As highlighted by Anbazhagan et al. [25], the increase in the angle of friction was due to the failure in the shearing zone. In the shearing zone, the tire shreds are oriented and randomly distributed at the shearing surface. As a result, the tire shreds particles resist against sliding, which leads to an increase in the angle of friction, which in turn leads to shearing among tire shred particles [57, 58]. Moreover, the cohesion also increases due to the inclusion of tire shreds in backfill material; the maximum cohesion value was attained. The cohesion does not always correspond to the highest shear strength parameters. The increase in cohesion is due to better interlocking between sand and tire shreds [59].

The results obtained were similar to the results reported by Marto et al. [60]. The shear strength of the tire chips-sand mixture was analyzed to determine the effectiveness of lightweight materials using the standard direct shear test apparatus. It was observed that the shear resistance of tire chips-sand mixture is higher than that of the sand-only mixture. The increase in tire chips content up to $20 \%$ (by weight) increases the internal friction angle from $32.8^{\circ}$ to $34.2^{\circ}$. Anbazhagan et al. [25] obtained similar results, that is, the shear strength increased significantly with the addition of granulated rubber up to $30 \%$ (by weight) in the sand. The friction angle for all rubber sizes varied from $35^{\circ}$ to $41^{\circ}$. The value of cohesion varied slightly with an increase in the size of the rubber. The cohesion value increased from 6.16 to $12.45 \mathrm{kPa}$ with the inclusion of rubber in the backfill mixtures.

Furthermore, Zornberg and coworkers [54] reported that the shear strength of tire shred-sand mixtures was affected by the tire shred content. The shear strength increases with increasing tire shred content, reaching a maximum value for a tire shred content of around $35 \%$, followed by a decrease beyond this value. The authors also confirmed that

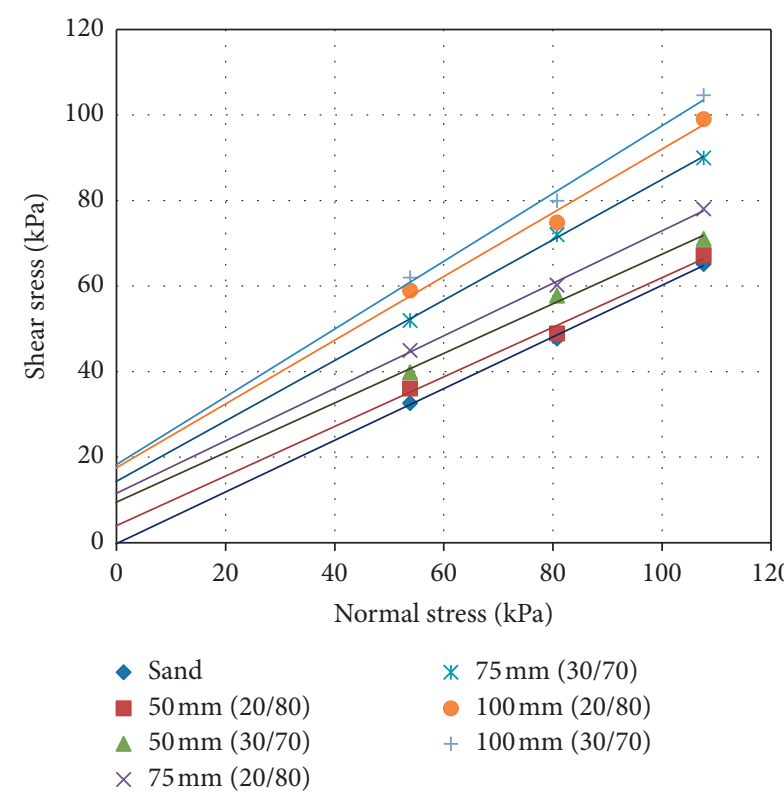

FiguRE 7: Shear stress versus normal stress plots for various sandonly and tire shred-sand mixtures with different tire shred sizes.

the maximum friction angle and cohesion values for tire shred-sand mixture were observed to be in the ranges of $26.5^{\circ}-44.5^{\circ}$ and $3.8-60 \mathrm{kPa}$, respectively.

4.1.2. Stress-Strain Behavior. Figure 8(a) presents the stressstrain plots for various backfill mixtures prepared with a tire shred size of $100 \mathrm{~mm}$ at constant vertical stress of $40 \mathrm{kPa}$. As is shown, the shear stress tends to increase with an increase in shear displacement for all backfill mixtures. Moreover, after reaching the peak value, the shear stress decreases with further increase in shear displacement. The stress-strain characteristics of the tire shred-sand backfill mixtures shift from brittle to ductile as the rubber fraction increases. The ductile characteristics of these backfill mixtures could be attributed to the combined effect of tire shred length, aspect ratio (length/diameter), stiffness of tires, the orientation of tire shreds, sand frictional angle, and applied normal stress $[61,62]$. Figure $8(\mathrm{~b})$ presents the stress-strain plots for sandonly $(0 / 100)$ and $20 / 80$ backfill mixtures for various tire shred sizes. As is shown, the increase in the size of tire shreds increases the ductility of backfill mixtures; i.e., compared with sand-only backfill mixture, gradual drop after peak stress is observed with increasing shear displacement [63]. The tire shreds serve as reinforcement, and sand fills the voids created due to the tire shred addition. Moreover, the lower stiffness and higher compressibility are the governing factors for the ductile behavior of tire shred-sand backfill mixtures [64].

4.2. Pull-Out Test Results. After the application of normal pressures, pull-out values and displacement of the deformed steel bar were calculated. Table 3 collects the pull-out capacities for samples prepared at different mixing ratios, tire shred size, and diameter of deformed steel bars. 
TABLE 2: Shear strength parameters obtained from LSDT at $40 \mathrm{kPa}$ normal stresses.

\begin{tabular}{lcccc}
\hline Sample & Cohesion $c(\mathrm{kPa})$ & Shear stress $\tau(\mathrm{kPa})$ & Normal stress $\sigma(\mathrm{kPa})$ & Angle of internal friction $\varphi$ \\
\hline Sand & 0 & 64 & 40 & $30.88^{\circ}$ \\
$50 \mathrm{~mm}(20 / 80)$ & 4 & 68 & 40 & $30.88^{\circ}$ \\
$50 \mathrm{~mm}(30 / 70)$ & 8.9 & 73 & 40 & $30.92^{\circ}$ \\
$75 \mathrm{~mm}(20 / 80)$ & 12.7 & 78 & 40 & $31.39^{\circ}$ \\
$75 \mathrm{~mm}(20 / 80)$ & 14.8 & 90 & 40 & $35.09^{\circ}$ \\
$100 \mathrm{~mm}(20 / 80)$ & 18.8 & 98 & 40 & $36.50^{\circ}$ \\
$100 \mathrm{~mm}(30 / 70)$ & 19 & 104 & 40 & $38.46^{\circ}$ \\
\hline
\end{tabular}

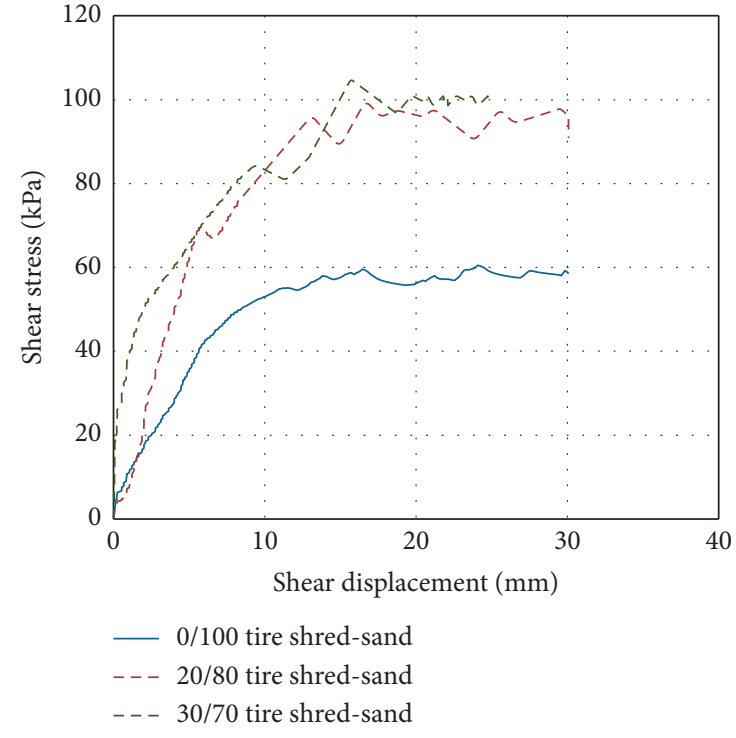

(a)

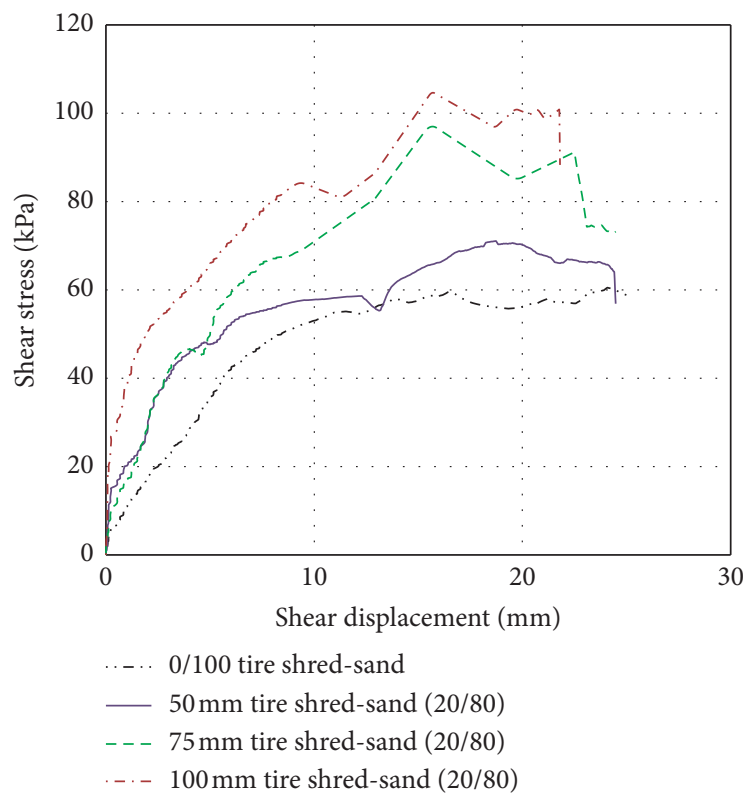

(b)

Figure 8: (a) Typical stress-strain plot for constant vertical stress of $40 \mathrm{kPa}$. (a) Various backfill mixtures prepared with a tire shred size of $100 \mathrm{~mm}$. (b) Sand-only (0/100) and tire shred-sand backfill mixture (20/80) for various tire shred sizes.

TABLE 3: Pull-out resistance of $12.7 \mathrm{~mm}$ bar and $15.8 \mathrm{~mm}$ deformed bars embedded in various backfill mixtures with different tire shred sizes.

\begin{tabular}{|c|c|c|c|c|c|}
\hline S/no. & $\begin{array}{l}\text { Size of the tire shred } \\
(\mathrm{mm})\end{array}$ & $\begin{array}{l}\text { Mixing } \\
\text { ratio }\end{array}$ & $\begin{array}{l}\text { Pull-out resistance of } 15.8 \mathrm{~mm} \\
\text { diameter bar }(\mathrm{kN} / \mathrm{m})\end{array}$ & $\begin{array}{l}\text { Pull-out resistance of } 12.7 \mathrm{~mm} \\
\text { diameter bar }(\mathrm{kN} / \mathrm{m})\end{array}$ & $\begin{array}{l}\text { Normal load } \\
\quad(\mathrm{kPa})\end{array}$ \\
\hline \multirow{3}{*}{1} & \multirow{3}{*}{ Only sand } & \multirow{3}{*}{ Only sand } & 4.1 & 2.8 & 20 \\
\hline & & & 4.7 & 4.3 & 30 \\
\hline & & & 5.3 & 5.3 & 40 \\
\hline \multirow{3}{*}{2} & \multirow{3}{*}{50} & \multirow{3}{*}{$20 / 80$} & 3.6 & 3.4 & 20 \\
\hline & & & 4.1 & 4.1 & 30 \\
\hline & & & 6 & 5 & 40 \\
\hline \multirow{3}{*}{3} & \multirow{3}{*}{50} & \multirow{3}{*}{$30 / 70$} & 4.2 & 4.2 & 20 \\
\hline & & & 4.8 & 5.8 & 30 \\
\hline & & & 7.4 & 8.1 & 40 \\
\hline \multirow{3}{*}{4} & \multirow{3}{*}{75} & \multirow{3}{*}{$20 / 80$} & 4.6 & 3.4 & 20 \\
\hline & & & 5.5 & 4.5 & 30 \\
\hline & & & 8.1 & 8.5 & 40 \\
\hline \multirow{3}{*}{5} & \multirow{3}{*}{75} & \multirow{3}{*}{$30 / 70$} & 6.2 & 5.1 & 20 \\
\hline & & & 6.9 & 6.2 & 30 \\
\hline & & & 7.8 & 8.6 & 40 \\
\hline \multirow{3}{*}{6} & \multirow{3}{*}{100} & \multirow{3}{*}{$20 / 80$} & 6.5 & 3.9 & 20 \\
\hline & & & 8.2 & 5.9 & 30 \\
\hline & & & 9.9 & 9.5 & 40 \\
\hline \multirow{3}{*}{7} & \multirow{3}{*}{100} & \multirow{3}{*}{$30 / 70$} & 7.9 & 5.6 & 20 \\
\hline & & & 8.8 & 8.1 & 30 \\
\hline & & & 9.7 & 9.2 & 40 \\
\hline
\end{tabular}


Table 4: Pull-out capacities and pull-out resistance factor $F^{*}$ for deformed bars no. 4 and no. 5 .

\begin{tabular}{|c|c|c|c|c|c|c|c|c|c|}
\hline \multirow[t]{2}{*}{ S/no. } & \multirow[t]{2}{*}{$\begin{array}{c}\text { Normal } \\
\text { load }(\mathrm{kPa})\end{array}$} & $\begin{array}{l}\text { Pull-out } \\
\text { resistance } \\
(\mathrm{kN} / \mathrm{m})\end{array}$ & $F^{*}$ & $\begin{array}{l}\text { Increase in pull- } \\
\text { out compared to } \\
\text { sand }(\%)\end{array}$ & $\begin{array}{l}\text { Increase in pull- } \\
\text { out compared to } \\
\text { normal load (\%) }\end{array}$ & $\begin{array}{l}\text { Pull-out } \\
\text { resistance } \\
(\mathrm{kN} / \mathrm{m})\end{array}$ & $\begin{array}{l}\text { Increase in pull- } \\
\text { out compared to } \\
\text { sand }(\%)\end{array}$ & $F^{*}$ & $\begin{array}{l}\text { Increase in } \\
\text { pull-out } \\
\text { compared to } \\
\text { normal load (\%) }\end{array}$ \\
\hline & & \multicolumn{4}{|c|}{$15.8 \mathrm{~mm}$ deformed bar } & \multicolumn{4}{|c|}{$12.7 \mathrm{~mm}$ deformed bar } \\
\hline 1 & 20 & 4.1 & 0.13 & - & - & 2.8 & - & 0.09 & - \\
\hline 2 & 30 & 4.7 & 0.1 & - & 14.6 & 4.3 & - & 0.09 & 53.5 \\
\hline 3 & 40 & 5.3 & 0.08 & - & 12.7 & 5.3 & - & 0.08 & 23.2 \\
\hline 4 & 20 & 3.6 & 0.11 & -12.1 & - & 3.4 & 21.4 & 0.11 & - \\
\hline 5 & 30 & 4.1 & 0.09 & -12.7 & 13.8 & 4.1 & 0 & 0.09 & 20.5 \\
\hline 6 & 40 & 6 & 0.09 & 13.2 & 46.3 & 5 & -5.6 & 0.08 & 21.9 \\
\hline 7 & 20 & 4.2 & 0.13 & 2.43 & - & 4.2 & 50 & 0.13 & - \\
\hline 8 & 30 & 4.8 & 0.1 & 2.12 & 14.2 & 5.8 & 34.8 & 0.12 & 38.1 \\
\hline 9 & 40 & 7.4 & 0.12 & 39.6 & 54.16 & 8.1 & 52.8 & 0.13 & 39.6 \\
\hline 10 & 20 & 4.6 & 0.14 & 12.1 & - & 3.4 & 21.4 & 0.11 & - \\
\hline 11 & 30 & 5.5 & 0.11 & 17 & 19.6 & 4.5 & 4.6 & 0.09 & 32.3 \\
\hline 12 & 40 & 8.1 & 0.13 & 52.8 & 47.2 & 8.5 & 60 & 0.13 & 88 \\
\hline 13 & 20 & 6.2 & 0.19 & 51.2 & - & 5.1 & 0 & 0.16 & - \\
\hline 14 & 30 & 6.9 & 0.14 & 46.8 & 11.2 & 6.2 & 44.1 & 0.13 & 21.5 \\
\hline 15 & 40 & 7.8 & 0.12 & 47.1 & 13 & 8.6 & 62.2 & 0.13 & 38.7 \\
\hline 16 & 20 & 6.5 & 0.2 & 58.5 & - & 3.9 & 39.2 & 0.12 & - \\
\hline 17 & 30 & 8.2 & 0.17 & 74.4 & 26.1 & 5.9 & 37.2 & 0.12 & 51.2 \\
\hline 18 & 40 & 9.9 & 0.15 & 86.7 & 20.7 & 9.5 & 79.2 & 0.15 & 61 \\
\hline 19 & 20 & 7.9 & 0.25 & 92.6 & - & 5.6 & 100 & 0.18 & - \\
\hline 20 & 30 & 8.8 & 0.18 & 87.2 & 11.39 & 8.1 & 88.3 & 0.17 & 44.6 \\
\hline 21 & 40 & 9.7 & 0.15 & 83 & 10.2 & 9.2 & 73.5 & 0.14 & 13.5 \\
\hline
\end{tabular}

Based on the results presented in Table 3, it is assessed that the pull-out resistance increases with an increase in tire shred size, the tire content (by weight percent), and the diameter of the deformed bar. Besides, the pull-out resistance of the deformed steel bar increases with an increase in normal pressure. These results are consistent with the findings by Balunaini and Prezzi [55]. Based on pull-out tests performed on ribbed metal strip embedded in tire shred-sand mixtures, the authors observed a higher pull-out capacity for ribbed metal strips embedded in tire shred-sand mixture compared with the metal strips embedded in the tire-only shred mixture. Mohan et al. [65] performed laboratory tests on ladder-type reinforcement placed in tire shred-sand mixture with different sizes of tire shreds ranging between $50 \mathrm{~mm}$ and $100 \mathrm{~mm}$. The results were then compared with the pull-out resistance of the ribbed steel bar. The results followed the same trend, such that an increase in size and content of tire shred (by weight) increased the pullout resistance from $4.2 \mathrm{kN} / \mathrm{m}$ to $9.7 \mathrm{kN} / \mathrm{m}$.

4.2.1. Effect of Normal Stress on Pull-Out Resistance. The influences of normal stress on the pull-out capacity of deformed bars embedded in various backfill mixtures are presented in Table 4 . All backfill mixtures (0/100, 20/80, and $30 / 70)$ prepared with different tire shred sizes $(50 \mathrm{~mm}$, $75 \mathrm{~mm}$, and $100 \mathrm{~mm}$ ) exhibited an increase in pull-out response with the increase in the normal stress. This finding was in agreement with the results obtained by Horpibulsuk and Niramitkornburee [66].
4.2.2. Pull-Out Resistance Factor $\left(F^{*}\right)$. The F* values calculated based on the pull-out capacities acquired from the tests are also given in Table 4. As observed, the pull-out resistance factor is inversely related to pull-out resistance i.e., with an increase in pull-out resistance, the pull-out resistance factor decreases. Furthermore, with respect to sand only backfill (0/100), the percentage increase in pull-out resistance factor for various tire shred-sand mixtures reinforced with $12.7 \mathrm{~mm}$ diameter deformed bars was in the range of $23.2-88 \%$. While the percentage increase in the pull-out resistance factor for $15.8 \mathrm{~mm}$ diameter bars embedded in the aforementioned mixtures was in the range of $12.7-54.6 \%$. These values are in agreement with the results obtained by [65].

4.2.3. Pull-Out Resistance vs. Displacement. Figures 9 and 10 show the pull-out resistance vs. displacement plots for 12.7 and $15.8 \mathrm{~mm}$ diameter deformed bars embedded in various backfill mixtures. Analyzing the graphs, it is assessed that pull-out resistances increase with the increase in normal stress levels for all backfill mixtures. The pull-out response curves for sand only mixtures showed a sharp decline in pull-out resistance after a peak value, indicating the brittle behavior. Conversely, for tire shred sand backfill mixtures, the pull-out resistance decreased gradually after peak values of pull-out resistance. The pullout response of backfill mixtures depends upon the type of reinforcement, nature of backfill material, and the 


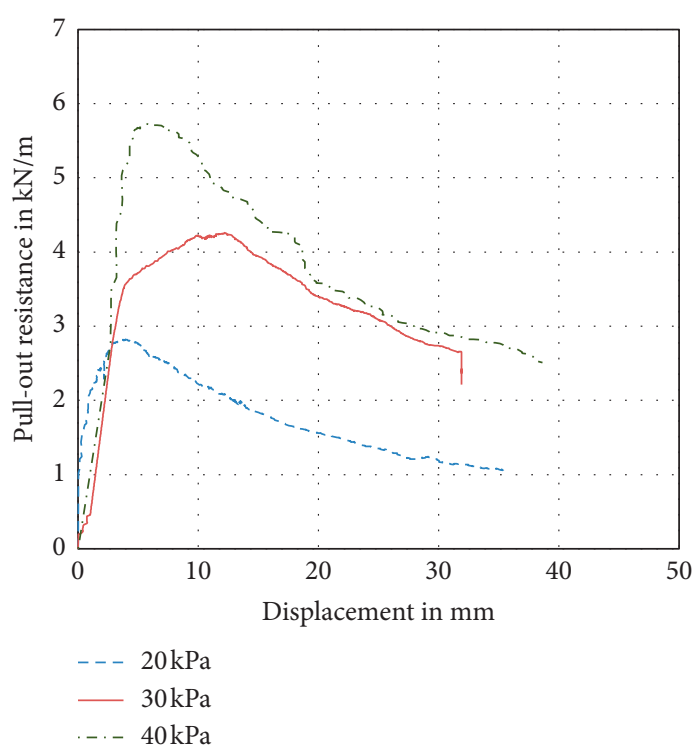

(a)

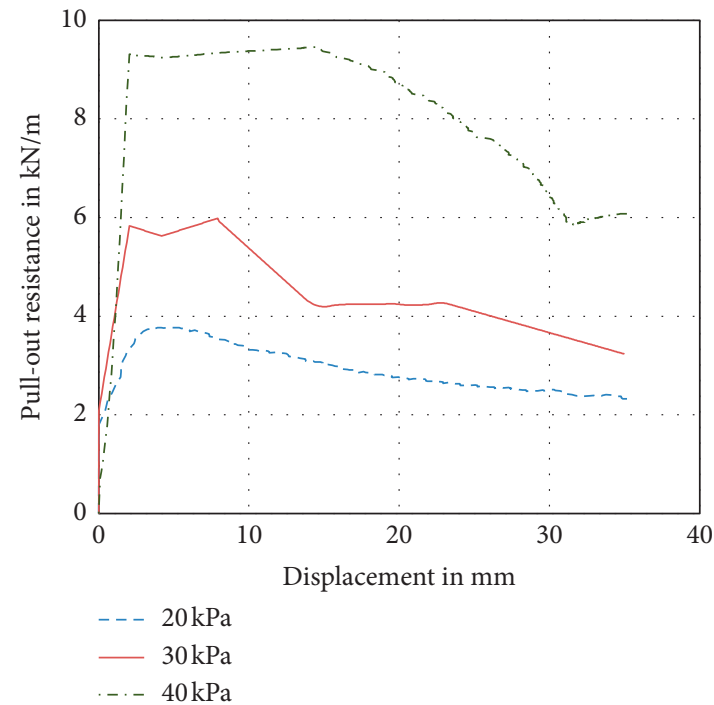

(c)

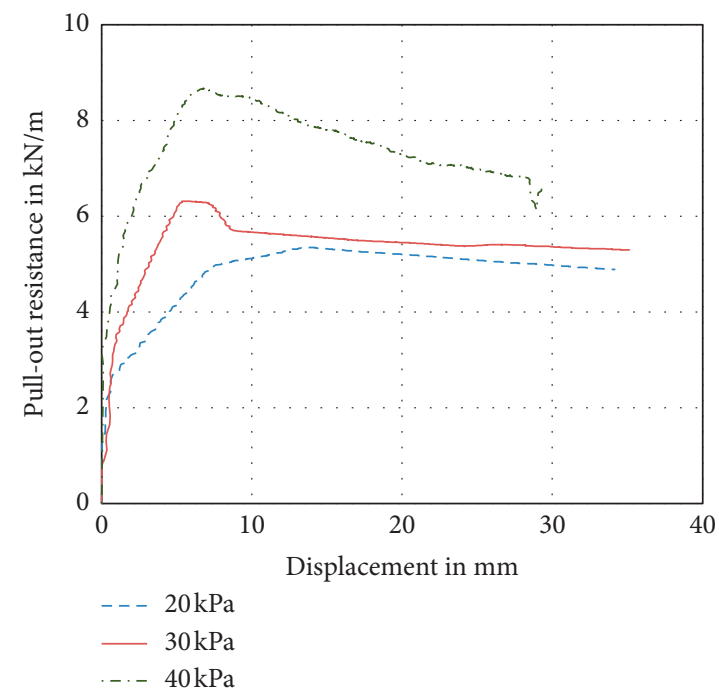

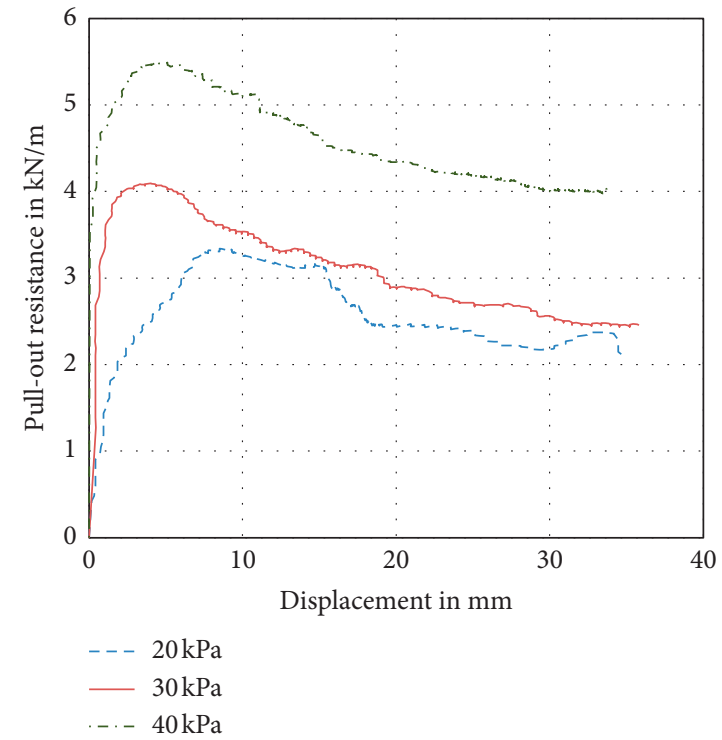

(b)

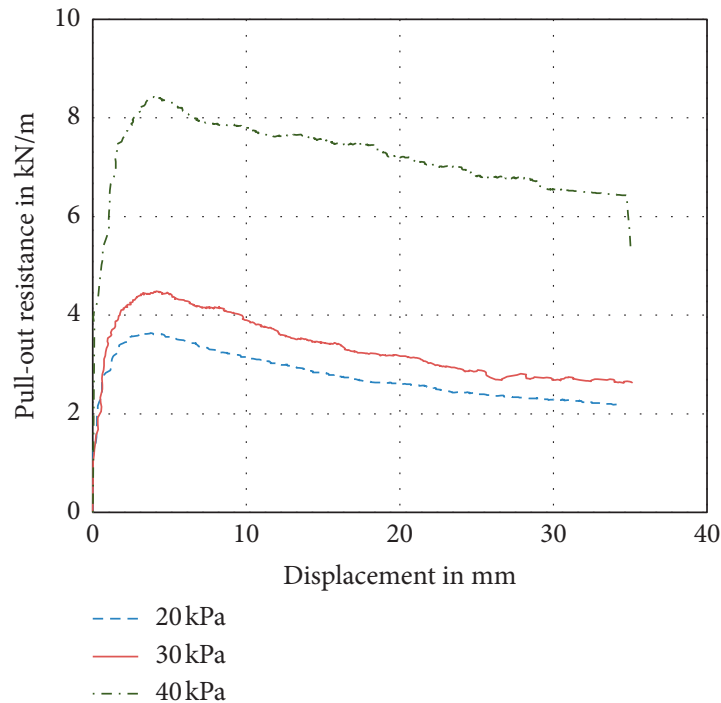

(d)

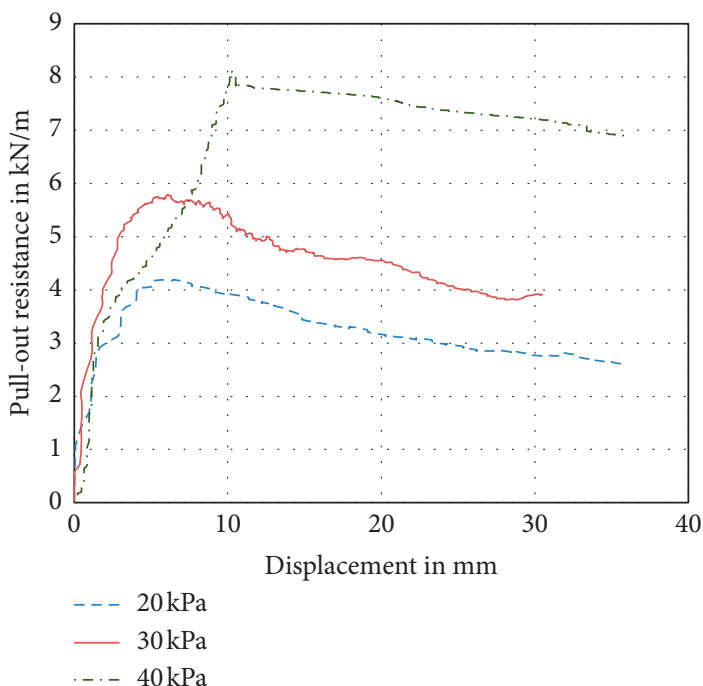

(f)

Figure 9: Continued. 


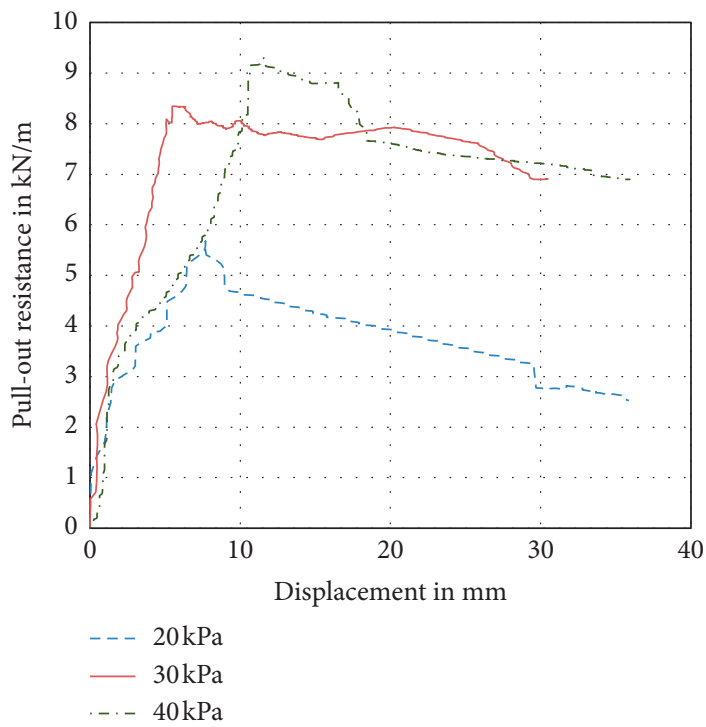

(g)

Figure 9: Pull-out resistance of $12.7 \mathrm{~mm}$ deformed steel bar at different stress levels embedded in (a) 0/100 and (b) 20/80 with $50 \mathrm{~mm}$ tire shred, (c) 30/70 with $50 \mathrm{~mm}$ tire shred, (d) 20/80 with $75 \mathrm{~mm}$ tire shred, (e) 30/70 with $75 \mathrm{~mm}$ tire shred, (f) 20/80 with 100 mm tire shred, and (g) 30/70 with $100 \mathrm{~mm}$ tire shred.

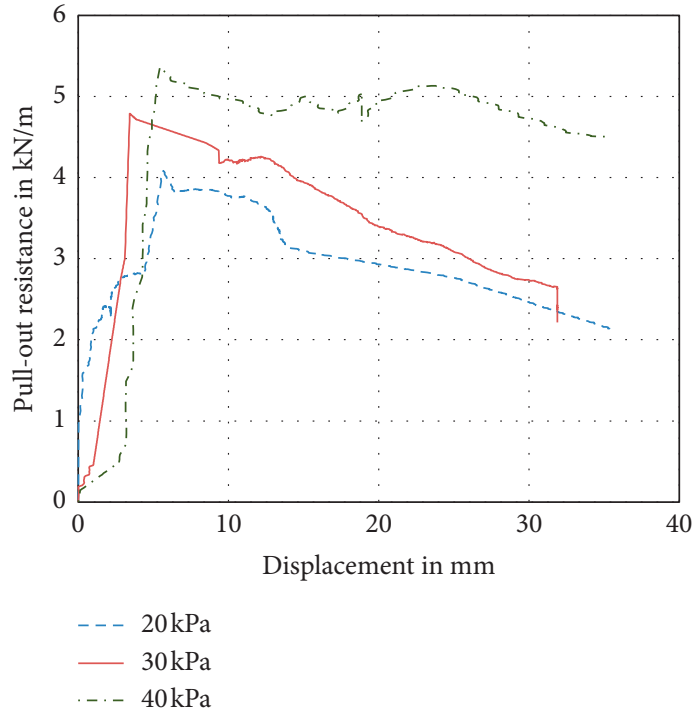

(a)

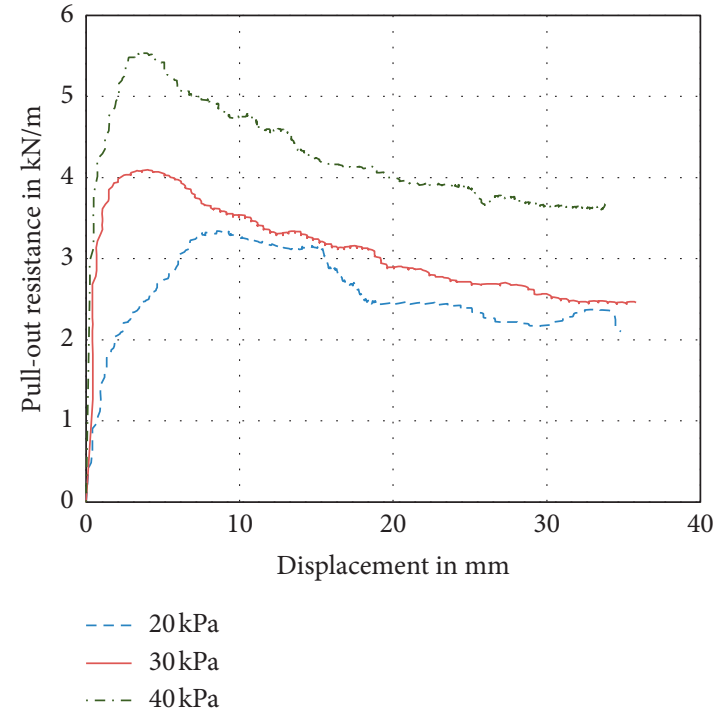

(b)

Figure 10: Continued. 


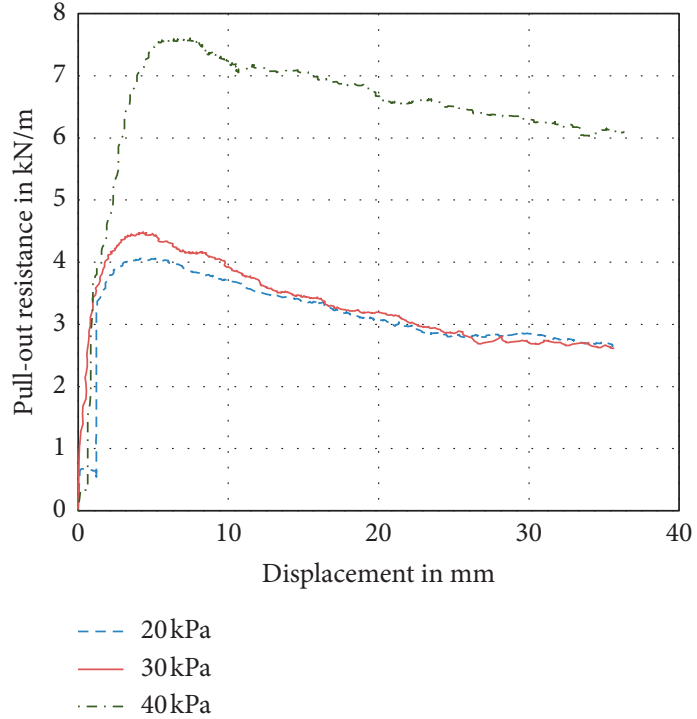

(c)

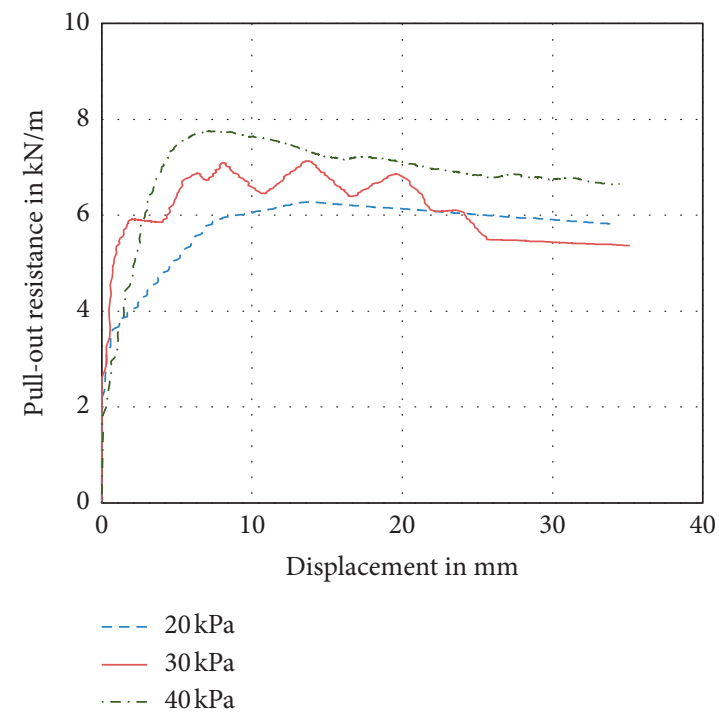

(e)

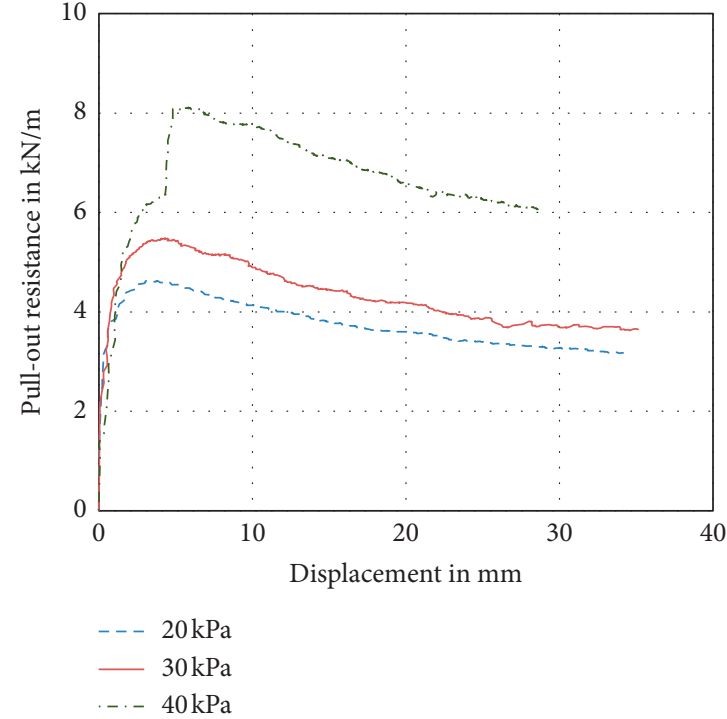

(d)

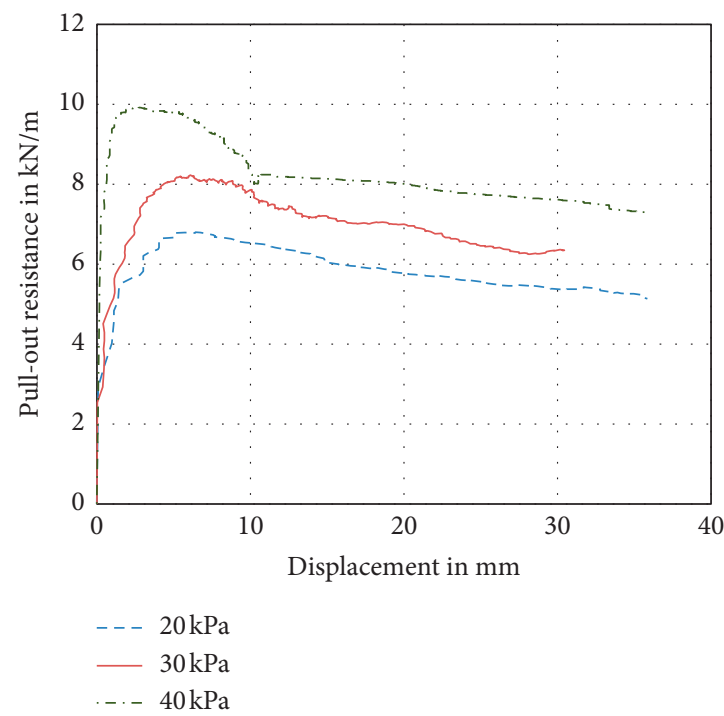

(f)

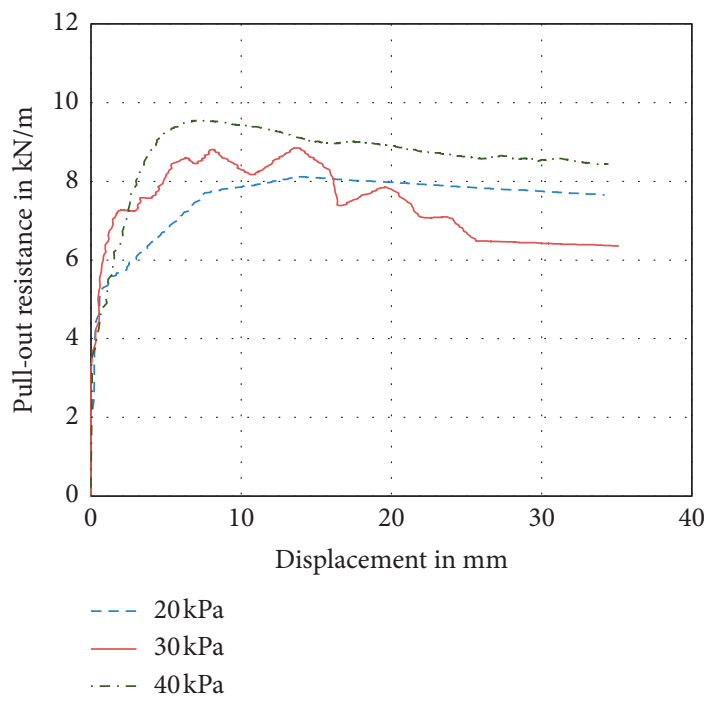

(g)

FIgURE 10: Pull-out resistance of $15.8 \mathrm{~mm}$ deformed steel bar at different stress levels embedded in (a) $0 / 100$ and (b) 20/80 with $50 \mathrm{~mm}$ tire shred, (c) 30/70 with $50 \mathrm{~mm}$ tire shred, (d) 20/80 with $75 \mathrm{~mm}$ tire shred, (e) 30/70 with $75 \mathrm{~mm}$ tire shred, (f) 20/80 with 100 mm tire shred, and (g) 30/70 with $100 \mathrm{~mm}$ tire shred. 
confinement pressures used. Furthermore, the ductility of backfill mixtures based on pull-out resistance seems to be largely affected by tire shred size and its content in the backfill mixture [7]. The increase in pull-out force due to an increase in tire size was possibly due to the following reasons: (1) the larger size tire particles creating more resistance with the box boundaries and (2) increase in the passive resistance [65].

\section{Conclusions}

This study was carried out in two stages; in the first stage, the large-scale direct shear test (LSDT) was performed to assess the shear strength parameters of tire shred-sand backfill mixtures in MSE walls. The effect of tire shred sizes and mix proportion of backfill mixtures was evaluated. The second stage of the study deals with the estimation of pull-out resistance of 12.7 and $15.8 \mathrm{~mm}$ bar diameter deformed steel bars embedded in tire shred-sand mixtures. The feasibility of using tire shred-sand mixture with deformed steel bars as reinforcement in backfill material for mechanically stabilized earth walls is elucidated. The large-scale direct shear apparatus was used for both the direct shear and pull-out test. The following conclusions were drawn from this study:

(i) The shear strength value is $64 \mathrm{kPa}$ for sand-only backfill, which increases to $104 \mathrm{kPa}$ for $30 / 70$ tire shred-sand mixture with $100 \mathrm{~mm}$ tire shred size. This is due to the increase in bonding between the particles.

(ii) The value of the angle of internal friction was observed to be $38.46^{\circ}$ for $30 / 70$ tire shred-sand mixture with $100 \mathrm{~mm}$ tire shred size compared with $30.88^{\circ}$ obtained for sand-only backfill mixture (0/ 100). The reason is that the tire shreds are randomly distributed at the shearing zone and thus offer higher resistance against sliding.

(iii) The cohesion also increases with the inclusion of tire shreds; its value increases from $0 \mathrm{kPa}$ to $19 \mathrm{kPa}$ obtained for sand-only backfill mixture (0/100) and 30/70 tire shred sand with $100 \mathrm{~mm}$ tire shred size, respectively. The cohesion increases because of the interlocking phenomenon between tire shreds and sand.

(iv) Based on stress-strain plots obtained from LSDT, ductility of tire shred backfill mixtures increases compared with sand-only backfill material.

(v) The pull-out capacity of $15.8 \mathrm{~mm}$ bar reinforcement embedded in 20/80 and 30/70 mixtures increased by $12.2-86.7 \%$ and $2.4-92.6 \%$, respectively, compared to sand alone for the range of normal stresses considered in the study. Similarly, the pull-out capacity of $12.7 \mathrm{~mm}$ bar reinforcement embedded in $20 / 80$ and $30 / 70$ mixtures increased by $4.6-79 \%$ and $34-100 \%$, respectively, compared to sand alone.

(vi) The pull-out capacities for sand-only backfill (0/ 100) embedding $12.7 \mathrm{~mm}$ and $15.8 \mathrm{~mm}$ diameter bars as reinforcement are $4.1 \mathrm{kN}$ and $2.8 \mathrm{kN}$, respectively. Meanwhile, the pull-out capacities for the same bars in tire-sand backfill mixture (30/70) with $100 \mathrm{~mm}$ tire shred size are observed to be $9.2 \mathrm{KN}$ and $9.7 \mathrm{kN}$, respectively. This can be attributed due to the higher interlocking force offered by projections of deformed steel bars against the tire shred pieces and due to the frictional resistance.

(vii) The pull-out resistance of the $15.8 \mathrm{~mm}$ diameter deformed bar is nearly $5.43 \%$ higher than the deformed bar having a diameter of $12.7 \mathrm{~mm}$. This is because of the increase in surface area, which imparts more frictional resistance.

\section{Data Availability}

The data used to support the findings of this study are included within the article.

\section{Conflicts of Interest}

The authors declare no conflicts of interest related to this article.

\section{Acknowledgments}

This work was supported by Higher Education Research Endowment Fund (Grant no. PMUI-22/HEREF/2014-15/ VOL-IV/3409).

\section{References}

[1] R. M. Association, US Scrap Tire Management Summary 2005-2009, Washington, DC, USA, 2011.

[2] A. Edincliler, A. F. Cabalar, and A. Cevik, "Modelling dynamic behaviour of sand-waste tires mixtures using Neural Networks and Neuro-Fuzzy," European Journal of Environmental and Civil Engineering, vol. 17, no. 8, pp. 720-741, 2013.

[3] M. Tajabadipour and M. Marandi, "Effect of rubber tire chipssand mixtures on performance of geosynthetic reinforced earth walls," Periodica Polytechnica Civil Engineering, vol. 61, no. 2, pp. 322-334, 2017.

[4] S. M. Anvari, I. Shooshpasha, and S. S. Kutanaei, "Effect of granulated rubber on shear strength of fine-grained sand," Journal of Rock Mechanics and Geotechnical Engineering, vol. 9, no. 5, pp. 936-944, 2017.

[5] M. Sharifi, M. Meftahi, and S. A. Naeini, "Influence of waste tire chips on steady state behavior of sand," Journal of Engineering Geology, vol. 12, no. 5, pp. 189-212, 2019.

[6] K. Terzaghi, R. B. Peck, and G. Mesri, Soil Mechanics in Engineering Practice, John Wiley \& Sons, Hoboken, NJ, USA, 1996.

[7] M. Tajabadipour, M. Dehghani, B. Kalantari, and S. H. Lajevardi, "Laboratory pullout investigation for evaluate feasibility use of scrap tire as reinforcement element in mechanically stabilized earth walls," Journal of Cleaner Production, vol. 237, Article ID 117726, 2019.

[8] D. Maine, "Pisacataquis river: maine river quality series, issue 1. document number: DEPLW2000-12. fall," 2000.

[9] A. Asefzadeh, L. Hashemian, and A. Bayat, "Fatigue life evaluation of pavement embankments made with tire derived aggregates," Canadian Journal of Civil Engineering, vol. 45, no. 9, pp. 795-802, 2018. 
[10] L. A. Jimoda, I. D. Sulaymon, A. O. Alade, and G. A. Adebayo, "Assessment of environmental impact of open burning of scrap tyres on ambient air quality," International Journal of Environmental Science and Technology, vol. 15, no. 6, pp. 1323-1330, 2018.

[11] Z. Enquan and W. Qiong, "Experimental investigation on shear strength and liquefaction potential of rubber-sand mixtures," Advances in Civil Engineering, vol. 2019, Article ID 5934961, , 2019.

[12] ASTM, D, 6270-08, Standard Practice for the Use of Scrap Tires in Civil Engineering Applications, ASTM, West Conshohocken, PA, USA, 1998.

[13] A. M. Mhaya, G. F. Huseien, A. R. Z. Abidin, and M. Ismail, "Long-term mechanical and durable properties of waste tires rubber crumbs replaced GBFS modified concretes," Construction and Building Materials, vol. 256, Article ID 119505, 2020.

[14] T. Polydorou, G. Constantinides, K. Neocleous et al., "Effects of pre-treatment using waste quarry dust on the adherence of recycled tyre rubber particles to cementitious paste in rubberised concrete," Construction and Building Materials, vol. 254, Article ID 119325, 2020.

[15] L. Liu, G. Cai, and X. Liu, "Investigation of thermal conductivity and prediction model of recycled tire rubber-sand mixtures as lightweight backfill," Construction and Building Materials, vol. 248, Article ID 118657, 2020.

[16] T. Edeskär, Technical and Environmental Properties of Tyre Shreds Focusing on Ground Engineering Applications, Luleå tekniska universitet, Luleå, Sweden, 2004.

[17] V. Cecich et al., "Use of shredded tires as lightweight backfill material for retaining structures," Waste Management \& Research, vol. 14, no. 5, pp. 433-451, 1996.

[18] A. Cabalar and Z. Karabash, "California bearing ratio of a subbase material modified with tire buffings and cement addition," Journal of Testing and Evaluation, vol. 43, no. 6, 2015.

[19] A. F. Cabalar, Z. Karabash, and W. S. Mustafa, "Stabilising a clay using tyre buffings and lime," Road Materials and Pavement Design, vol. 15, no. 4, pp. 872-891, 2014.

[20] U. Balunaini et al., Tire Shred Backfill in Mechanically Stabilized Earth Wall Applications, Purdue University, West Lafayette, Indiana, 2009.

[21] G. Pistolas, A. Anastasiadis, and K. Pitilakis, "Dynamic behaviour of granular soil materials mixed with granulated rubber: effect of rubber content and granularity on the smallstrain shear modulus and damping ratio," Geotechnical and Geological Engineering, vol. 36, no. 2, pp. 1267-1281, 2018.

[22] K. H. Lepcha et al., "Application of tire chips in reinforcement of soil?: a review," Journal of Civil Engineering and Environmental Technology, vol. 1, no. 5, pp. 51-53, 2014.

[23] J. L. Perez, C. Kwok, and K. Senetakis, "Effect of rubber size on the behaviour of sand-rubber mixtures: a numerical investigation," Computers and Geotechnics, vol. 80, pp. 199-214, 2016.

[24] X.-Y. Jing, W.-H. Zhou, and Y. Li, "Interface direct shearing behavior between soil and saw-tooth surfaces by DEM simulation," Procedia Engineering, vol. 175, pp. 36-42, 2017.

[25] P. Anbazhagan, D. R. Manohar, and D. Rohit, "Influence of size of granulated rubber and tyre chips on the shear strength characteristics of sand-rubber mix," Geomechanics and Geoengineering, vol. 12, no. 4, pp. 266-278, 2017.

[26] P. Riahi, R. Chenari, and M. Karimpour-Fard, "Mechanical properties of sand-TDA mixtures in large scale direct shear test," in Proceedings of the Geotechnical Engineering
Infrastructure Development, pp. 3323-3328, ICE Publishing, London, UK, September 2015.

[27] M. S. Mashiri, J. S. Vinod, M. N. Sheikh, and H.-H. Tsang, "Shear strength and dilatancy behaviour of sand-tyre chip mixtures," Soils and Foundations, vol. 55, no. 3, pp. 517-528, 2015.

[28] M. Xiao, J. Bowen, M. Graham, and J. Larralde, "Comparison of seismic responses of geosynthetically reinforced walls with tire-derived aggregates and granular backfills," Journal of Materials in Civil Engineering, vol. 24, no. 11, pp. 1368-1377, 2012.

[29] S. Yoon, Mechanical Response of Tire Shred-Sand Mixtures and Applicationsto Geotechnical Structures, Purdue University, West Lafayette, Indiana, 2006.

[30] R. J. Bathurst, "Developments in MSE wall research and design," in International Congress and Exhibition "Sustainable Civil Infrastructures"Springer, Berlin, Germany, 2019.

[31] V. Elias, Mechanically Stabilized Earth Walls and Reinforced Soil Slopes: Design and Construction Guidelines, US Department of Transportation, Federal Highway Administration, Washington, D.C., USA, 2001.

[32] A. V. Thakre et al., "An experimental and numerical investigation of mechanically stabilized earth wall," in Proceedings of the NCAETAS-2019Maharashtra, India, March 2019.

[33] J. S. McCartney et al., "Large-scale combination direct shear/ simple shear device for tire-derived aggregate," Geotechnical Testing Journal, vol. 41, no. 2, pp. 340-353, 2018.

[34] M. Simac et al., National Concrete Masonry Association Segmental Retaining Wall Design Manual, National Concrete Masonry Association, Herdon, VA, USA, 1993.

[35] T. Allen and R. Bathurst, "Geosynthetic reinforcement stiffness characterization for MSE wall design," Geosynthetics International, vol. 27, no. 5, pp. 1-19, 2019.

[36] S. B. Reddy and A. M. Krishna, "Recycled tire chips mixed with sand as lightweight backfill material in retaining wall applications: an experimental investigation," International Journal of Geosynthetics and Ground Engineering, vol. 1, no. 4, p. 31, 2015.

[37] M. Hossain et al., "Effects of backfill soil on excessive movement of MSE wall," Journal of Performance of Constructed Facilities, vol. 26, no. 6, pp. 793-802, 2011.

[38] A. Tsiavos, N. A. Alexander, A. Diambra et al., "A sand-rubber deformable granular layer as a low-cost seismic isolation strategy in developing countries: experimental investigation," Soil Dynamics and Earthquake Engineering, vol. 125, Article ID 105731, 2019.

[39] S. Bali Reddy, D. Pradeep Kumar, and A. Murali Krishna, "Evaluation of the optimum mixing ratio of a sand-tire chips mixture for geoengineering applications," Journal of Materials in Civil Engineering, vol. 28, no. 2, Article ID 06015007, 2015.

[40] A. Bernal, R. Salgado, R. H. Swan, and C. W. Lovell, "Interaction between tire shreds, rubber-sand and geosynthetics," Geosynthetics International, vol. 4, no. 6, pp. 623-643, 1997.

[41] B. Umashankar, M. Prezzi, and R. Salgado, "Pullout resistance factors of metal strips in tire shred-sand mixtures," Geoenvironmental Engineering, pp. 232-241, 2014.

[42] C. Suksiripattanapong, S. Horpibulsuk, A. Chinkulkijniwat, and J. C. Chai, "Pullout resistance of bearing reinforcement embedded in coarse-grained soils," Geotextiles and Geomembranes, vol. 36, pp. 44-54, 2013.

[43] C. Suksiripattanapong et al., "Pullout resistance mechanism of bearing reinforcement embedded in coarse- 
grained soils: laboratory and field investigations," Transportation Geotechnics, vol. 22, Article ID 100297, 2019.

[44] M. J. Rahmeyer, "Developing more efficient mechanically stabilized earth (MSE) wall reinforcements," M. Sc. thesis, Utah State University, Logon, Utah, 2016.

[45] D. T. Pond, Alternative Steel Reinforcement in Mechanically Stabilized Earth (MSE) Walls, M. Sc. thesis, Utah State University, Logon, Utah, 2013.

[46] ASTM, Standard Test Method for Particle-Size Analysis of Soils (D422-63), ASTM International, West Conshohocken, PA, USA, 2007.

[47] R. R. Berg, N. C. Samtani, and B. R. Christopher, Design of Mechanically Stabilized Earth Walls and Reinforced Soil Slopes, United States. Department of Transportation. Federal Highway Administration, Washington, DC, USA, 2009.

[48] W. Chesner, R. Collins, and M. Mackay, User Guidelines for Waste and Byproduct Materials in Pavement Construction (Publication No. FHWA-RD-97-148), Federal Highway Administration, US Department of Transportation, Washington, DC, USA, 1998.

[49] ASTM 698-00a, "Standard test method for laboratorycompaction characteristics of soil using standard effort," pp. 78-87, Annual Book of ASTM Standards. American Society for Testing and Materials, West Conshohocken, PA, USA, 2003.

[50] U. Balunaini, S. Yoon, M. Prezzi, and R. Salgado, "Pullout response of uniaxial geogrid in tire shred-sand mixtures," Geotechnical and Geological Engineering, vol. 32, no. 2, pp. 505-523, 2014.

[51] D. Astm, ": standard test method for direct shear test of soils under consolidated drained conditions," Annual Book of ASTM Standards, vol. 4, pp. 290-295, 3080-90.

[52] G. J. Foose, Shear Strength of Sand Reinforced with Shredded Waste Tires, University of Wisconsin-Madison, Madison, Wisconsin, 1993.

[53] H. Hazarika and K. Yasuhara, Scrap Tire Derived Geomaterials-Opportunities and Challenges: Proceedings of the International Workshop IW-TDGM 2007 (Yokosuka, Japan, 23-24 March 2007), CRC Press, Boca Raton, FL, USA, 2007.

[54] D-01 ASTM, Standard Test Method for Measuring Geosynthetic Pullout Resistance in Soil, ASTM International West, Conshohocken, PA, USA, 2013.

[55] U. Balunaini and M. Prezzi, "Interaction of ribbed-metal-strip reinforcement with tire shred-sand mixtures," Geotechnical and Geological Engineering, vol. 28, no. 2, pp. 147-163, 2010.

[56] G. J. Foose, C. H. Benson, and P. J. Bosscher, "Sand reinforced with shredded waste tires," Journal of Geotechnical Engineering, vol. 122, no. 9, pp. 760-767, 1996.

[57] Y. Yoon, S. Cho, and K. Kim, "Engineering properties of tire treads for soil reinforcement," Journal of the Korean Geoenvironmental Society, vol. 8, no. 1, pp. 49-55, 2007.

[58] S. Youwai and D. T. Bergado, "Strength and deformation characteristics of shredded rubber tire - sand mixtures," Canadian Geotechnical Journal, vol. 40, no. 2, pp. 254-264, 2003.

[59] W. Li, C. Y. Kwok, and K. Senetakis, "Effects of inclusion of granulated rubber tyres on the mechanical behaviour of a compressive sand," Canadian Geotechnical Journal, vol. 57, no. 5, 2019.

[60] A. Marto et al., "Shear properties of sand-tire chips mixtures," Electronic Journal of Geotechnical Engineering, vol. 18, no. 2, pp. 325-334, 2013.

[61] D. Humphrey, "Tire derived aggregate as lightweight fill for embankments and retaining walls," in Proceedings of the international workshop on scrap tire derived geomaterials-opportunities and challenges, IW-TDGM, Yokosuka, Japan, March 2007.

[62] M. Xiao, M. Ledezma, and C. Hartman, "Shear resistance of tire-derived aggregate using large-scale direct shear tests," Journal of Materials in Civil Engineering, vol. 27, no. 1, Article ID 04014110, 2013.

[63] P. Ni, X. Qin, and Y. Yi, "Use of tire-derived aggregate for seismic mitigation of buried pipelines under strike-slip faults," Soil Dynamics and Earthquake Engineering, vol. 115, pp. 495-506, 2018.

[64] T. Zhang, G. Cai, and W. Duan, "Strength and microstructure characteristics of the recycled rubber tire-sand mixtures as lightweight backfill," Environmental Science and Pollution Research, vol. 25, no. 4, pp. 3872-3883, 2018.

[65] V. K. D. Mohan et al., "Pullout capacity of ladder-type metal reinforcements in tire shred-sand mixtures," Construction and Building Materials, vol. 113, pp. 544-552, 2016.

[66] S. Horpibulsuk and A. Niramitkornburee, "Pullout resistance of bearing reinforcement embedded in sand," Soils and Foundations, vol. 50, no. 2, pp. 215-226, 2010. 